\title{
Study on Corporate Governance Structure of Nonprofit Private Universities based on Good Governance
}

\author{
Jingyang Liu $^{1, a}$ \\ ${ }^{1}$ Xi'an Fanyi University, Xi'an, Shaanxi, 710105 \\ ${ }^{a}$ email
}

\begin{abstract}
Keywords: Corporate Governance Structure; Non-Profit Private Colleges and Universities; Good
\end{abstract} Governance

\begin{abstract}
Nonprofit Private Universities Corporate governance structure is unique, its special performance in the organization and legal status of the interests counterpart relations, organizational performance assessment methods, and public responsibility mission. Good Governance stressed elements rule of law, legal, transparency, accountability, in line with the corporate governance structure to build a non-profit private colleges and universities principles and requirements. According to the non-profit Private Universities corporate governance structure characteristics, based on good governance proposed teaching improve the corporate governance structure of the non-profit private colleges and universities profit strategy
\end{abstract}

\section{Introduction}

Refers to a non-profit private colleges and universities outside the state institutions of social organizations or individuals using non-financial funds, community-oriented higher education courses organized by the school, the key difference between the non-profit private colleges and universities and for-profit private colleges and universities is donated school donors whether the distribution of profits powers donors nonprofit private colleges and universities do not enjoy the right to operate schools generate revenue obtained profits to the school development of the school. However, the lack of strength of running schools, part of the non-profit private colleges and universities do not meet profit requirements. Actual operations, non-profit private colleges and universities enjoy the advantage of the policy, while enjoying school operators for distribution of profits [1]. Although the Government has enacted policies to promote the development of non-profit private colleges and universities. Private Universities transition to a non-profit cause many problems the corporate governance structure of universities, colleges and universities as a single member of the Board, and presents family-oriented characteristics [2]. Educational administrative departments out of position, the university internal legal control over the frequency of the struggle. Good governance is an order to maximize the public interest for the purpose of the concept of governance, and the characteristics of the spirit of good governance and the idea of Private Colleges nonprofit governance philosophy fits perfectly. Therefore, this article from the perspective of good governance, based on a non-profit private colleges and universities to improve the corporate governance structure to propose a solution.

\section{Characteristics and Problem}

Corporate governance structure originated in the company profit corporation, when the study of separation of ownership and management interests of executives and corporate checks and balances among stakeholders. However, the powers vested in profit and nonprofit legal issues are not completely the same, can not fully cover the company's corporate governance structure for the non-profit private colleges and universities, non-profit corporate governance structure of private colleges and universities is unique.

Non-profit organization with corporate, private, non-profit distribution, autonomy and voluntary five features, civil, non-profit distribution and autonomy of the core features, a non-profit private colleges and universities to distinguish between corporate bodies corporate, government the basic 
characteristics and its subsidiary bodies. Special non-profit organization and legal status of private colleges and universities also create new problems, such as a non-profit distribution, how to make the active managers make decisions. Another example in civil and autonomy, the supervision mechanism and how to develop incentives Private Universities nonprofit legal entity.

Important theoretical corporate governance structure is the separation of ownership and control in the for-profit institution, the owner consciously take effective measures to control who their incentive to maximize the benefits and work. For example, the owner must give the controller a surplus or surplus property distribution of power, the control by self-motivation and supervision. However, a non-profit private colleges and universities surplus allocation body does not exist, university donors do not enjoy ownership of resources, have the right to allocate the remaining assets, a non-profit private colleges and universities can not be controlled through incentives given to income or property distribution rights. Although some of the non-profit private colleges and universities to solve the problem of corporate governance by way of shares, but the measure does not consider the special circumstances of the non-profit private colleges and universities, for-profit copying corporate governance model is not consistent with its characteristics [3].

Non-profit private colleges and universities have a special relationship affect the governance structure, such as donors and beneficiaries separated from each other donors can not allocate surplus. Universities and separated from each other donors and the beneficiary students, donors can not evaluate the quality of legal services to colleges and universities. These features lead to a lack of motivation Private Universities Corporate management and supervision, prone to corruption. In addition, stakeholder theory is that the interests of stakeholders should be consistent with the interests of shareholders, namely the College directors, managers should be for their own services, including stakeholders. The absence of the owner of the non-profit private colleges and universities, colleges and universities also have services with public service features, we need to let stakeholders participate in the legal supervision of non-profit private colleges and universities.

There are obvious differences in performance measurement and performance evaluation for-profit companies nonprofit private colleges and universities, non-profit private colleges and universities performance evaluation of the lack of clear profit targets, profit targets can not be used to measure the performance of colleges and universities, you can not use a democratic poll, which the nonprofit private the existence of complex and hysteresis characteristics of university performance evaluation, which is also reflected in the many non-profit educational services evaluation [4]. Problem-based organizational performance evaluation and incentive and monitoring system of non-profit private colleges and universities are often a problem, and its impact corporate governance institutions.

Public responsibility is an important theme of the governance structure of non-profit organizations, non-profit organization is the ultimate goal, but the mission of the nonprofit Public Responsibility Private Colleges more blurred. Responsibility for the corporate governance structure that is accountable to the shareholders, the government is accountable to the public rests with the voters, corporations and government accountability. But the interests of the non-profit private colleges and universities related to many people, but also the responsibility of the object diversified characteristics. Each stakeholder is very important, but demand contradiction between stakeholders easily lead to a non-profit private colleges and universities into "difficult to reach" dilemma. Based on a special non-profit private colleges and universities public responsibility mission, its corporate governance mechanism design also need to consider the "owner" of the absence of problems, problems of incentives and supervision mechanisms.

\section{Non-Profit Colleges Countermeasures based on Good Governance Perspective}

Good governance is a kind of public interest for the purpose of maximizing the concept of governance, the rule of law including good governance, legality, transparency, accountability, and effective response to six basic elements. The concept of good governance from political science, and then be gradually applied to the non-political field. China has been the concept of good governance researchers for student management work and achieved remarkable results. 
Characteristic elements of good governance, the spirit and the basic requirements of nonprofit governance Private Colleges and objective goals fit.

First, in line with the requirements for educational purposes. Non-profit private colleges and universities belong to higher education service agencies, colleges and universities need to train people management services. Improve the corporate governance structure conducive environment to create a good university governance from top to bottom, to better achieve the purpose of training people [5]. Pay attention to the legal concept of good governance, emphasizing transparency and accountability, human environment and school culture fit, help enhance students' sense of responsibility and sense of the rule of law.

Second, the pursuit of the same goal. Good governance nonprofit private colleges and universities are seeking to maximize the public interest, the driving force of the non-profit private colleges and universities for the public goal, the ultimate goal of good governance is to maximize the public interest. Thus, the pursuit of the ultimate goal of a non-profit private colleges and universities have consistency and good governance.

Under the existing legal framework, combined with the special nature of the theory of good governance and corporate governance structure of the non-profit, non-profit corporate governance structure of private colleges and universities can be improved from the following aspects.

The first corporate governance structure established as the core framework for the chairman, board of directors, principals, independent internal oversight bodies and constraints. Current corporate governance structure of the non-profit private colleges and universities vary, the advantages of various types of corporate governance structure is different. However, different structures easily lead to differences in division of responsibilities, can not be implemented unified supervision. Therefore, for the national requirements for private colleges and universities, non-profit private colleges and universities need to establish a board of directors as the core legal body, the board of directors, the rights belong to the principal organs and executive bodies, internal oversight in part, internal discipline department. Currently many private schools in developed countries have established a board of directors as the core of corporate governance mechanism [6]. Korea related laws such as the corporate governance structure of private schools have a clearly defined framework, companies must set up legal entities in accordance with certain rules.

Second, by law or regulation in the form of a clear corporate governance structure, terms of reference, and other incentives. Board nonprofit private colleges and universities is the hub of power, decision-making and responsible for coordination of foreign schools. The main reason for the dispute and the powers of the Board of Directors is a non-profit private school system is not perfect, and therefore need to improve the details of the board of directors system. Board internal structure, you need to specify the details of the number of personnel, board members and the method of qualification, term of office; power aspects need to be laws or regulations expressly define the scope of the powers and responsibilities of the Board, the directors to prevent interference teaching. Incentives, can learn the reputation mechanism, limit the use of the reputation of the Board of behavior. Use reputation mechanisms need to select people from other schools, both can learn from the experiences of other schools, but also can promote the maintenance of personal reputation and to participate in activities of the Board.

Third, to clear the board and donors, power relations between the president and the government. For the board of directors and donors, donors or their representatives are usually members of the Board of Directors, the Board of Directors to exercise their rights. But the power of the non-profit private university donors and investment shareholders are essentially different, and therefore the board of donors that has the qualifications to exercise the powers of the Board, not the board of donors agreed only enjoy power, such as the right to information, the right to question and supervision right. For the Board of Directors with the principal, the principal is the specific executive Board decided, the principal duties in accordance with the provisions of the Constitution [7]. For the Board of Directors and the Government, as a non-profit private colleges and universities belong to autonomous operations, and non-profit private colleges and universities have the characteristics of public welfare, which government authorities play a supervisory role of the Board 
of Directors. The current government acts, there are still many problems, the need to legislate manner prescribed clearly defined relationship between the Government and the Board of Directors.

Fourth, strengthen the government's external supervision of legal persons. Foreign law attaches great importance to the supervision of non-profit educational institutions, such as the board of directors in private educational institutions or schools can not function properly in case of insolvency, the government can be forced to intervene. Our government double layered supervision and management system, that is, double the supervision of education authorities and civil affairs departments. But the government is difficult to implement a number of non-profit private colleges and universities to effective supervision and therefore need to be further strengthened external supervision of the government, in order to avoid the absence of government or out of position.

Fifth, to play a stakeholder oversight. Our donors nonprofit private colleges and universities less, weak supervision power of donors. Although students have oversight responsibilities, but the law does not give the student supervisory powers. Therefore, to play a stakeholder oversight, public schools need the information-for-profit private colleges and universities, transparent accountability, can play a supervisory role stakeholders.

\section{Acknowledgements}

Project: A Key Research Project in 2015 Supported by Xi'an Fanyi University(15A07).

\section{References}

[1] Wang Li. On the Perfection of University Wang Li of China 's Corporate Governance Structure in Private - Stakeholders' Rights balanced perspective [J]. Tianjin Academy of Educational Science, 2011,06: 16-18.

[2] Chen Lu. Internal Governance Research Good Governance for-profit private colleges and universities [D]. Huazhong Normal University, 2012.

[3] Pan Liuxian, Chen Wenlian. Constructing a non-profit private colleges and universities constraint mechanism [J] China Higher Education Research, 2015,02: 86-90.

[4] Rong Zhenhua, Liu Yilin. alienation corporate governance structure under the Perspective of Private Colleges and Universities category management guidance [J] Modern Education Management, 2015,05: 118-122.

[5] Zhou Haitao, Shi Wenmei. Challenges and strategies to improve the corporate governance structure of Private Colleges [J] Higher, 2015,04: 13-16 + 95.

[6] Liu Jianyin. perspective from the perspective of non-profit organizations Private School Corporate Governance [J] Private Education Research, 2008,04: 74-80 + 108.

[7] Yin Yonglon, Dai Lei. Behalf of the bud and Measures of Perfecting the Corporate Governance Structure in Private Colleges and Universities [J]. Value Engineering, 2014,10: 242-243. 